\title{
Employee's' Perception on E-Banking Services in Banks in Chennai
}

\author{
V. Jayanthi, S. Subbulakshmi, T. Devi Kamatchi
}

\begin{abstract}
Indian banking industry has been pushed to a crucial transformation phase towards cashless economy. E-banking eliminates corruption and illegal transactions. The bank employees have to cope with and adopt the changes in the technology from time to time. The expectations of customers keep changing and increase with the technological developments. E-services are concerned with security and safety though provided with $24 * 7$ services. This paper attempts to hit upon the perceptions of bank employees.
\end{abstract}

Key words: Banking Sector, Information Technology, E-services, Bank employees

\section{INTRODUCTION}

In the present world of technology both mode of production but also the services marketing are affected. The acceptance of IT enabled services in the service sector is mandatory. Especially in banking sector, the employees' perception and reception of technology plays a vital role in the accomplishment of any bank. This study gains significance as there are no many studies pertaining to the employees. The problems and insight of bank employees affects the service rendered by them.

\section{REVIEW OF LITERATURE}

$\checkmark$ R. K. Uppal in his paper on E- banking: Problems and Prospects: An Empirical study in Punjab, Information management and Business Review (2011), studied the problems and prospects of E-banks in India. The findings of the study showed that $50 \%$ of Indian banking customers have used E - channels. Online banking was not familiar among old aged and middle aged people as much as youngsters. The study concluded with a suggestion to public sector banks to formulate innovative strategies to compete with the foreign and private sector banks.

$\checkmark$ R.K.Uppal in his article "Internet Banking problems and future on look" examined the perceptions of bankers on Internet based E-banking services related with important issues like collaborative culture, training \& development and knowledge management. E-banks have helped to do routine work more efficiently and increased interest in work. Analysing the problems faced by the employees while

Revised Version Manuscript Received on August 19, 2019.

Dr.V. Jayanthi, Asst Professor, Dept of Business Administration, Vels Institute of Science, technology \& Advanced Studies (VISTAS), ChennaiTamil Nadu, India.(Email: jayanthiii.murali@gmail.com)

Dr. S. Subbulakshmi,Head and Asso Professor, PG Dept of Commerce, SDNB Vaishnav College, Chennai, Tamil Nadu, India.(Email: subbupetchi72@gmail.com)

Dr. T. Devi Kamatchi,Asst Prof, Dept of Commerce, A.M. Jain College, Meenambakkam, Chennai, Tamil Nadu, India.(Email: iyaneshkamatchi@gmail.com) dealing with customers electronically, illiteracy and increased expectations of customers and lack of knowledge came out to be the main problems. The researcher has given certain policy, recommendations to make employees more efficient like effective on the job training, establishment of separate human resources departments and friendly work environment.

\section{IMPORTANCE OF THE STUDY}

Now days, most of the banks are providing diversified facilities to its customers. Some of the facilities are credit card, debit card, ATM card, E-Banking, Mobile Banking, Loan facilities, etc. Many of these facilities are really useful for the users and helping them to save time. This study is confined to measure the bank employee's perception and their level of satisfaction on their performance (i.e. services and products provided) of public banks, private banks \& foreign banks in Chennai City.

\section{OBJECTIVES OF THE STUDY}

* . To study the perception of bank employees of all the three types of bank.

* To understand the factors influencing the service quality dimension of the banks

* To study the attitude and behaviour of employees relating to e- services

* To offer suggestions for improvement of quality of services in banks.

Hyphotheses

H0: There is no significant difference between various bank group employees in the perception of E-banking services.

H1: There is significant difference between various bank group employees in the perception of E-banking services.

\section{LIMITATIONS OF THE STUDY}

1) The study is made in Chennai city only.

2) Only 338 respondents have been taken for the study.

3) The selected banks have alone been considered for the study.

4) Time and cost are the factors limiting the study 


\section{RESEARCH METHODOLOGY\& RESULTS}

Analytical research study has been adopted. Sample of 338 respondents were chosen from Public sector, private sector and foreign banks. Convenience sampling technique was used for collection of data. Primary Data collected through structured questionnaire with multiple choices was framed for this purpose. Secondary data collected from websites, journals, projects and other publications. Percentage Analysis, ANOVA. POST HOC TEST \& TUSKY HSD tools used to analyse the data

Table 1- Demographic Profile of Respondents

\begin{tabular}{|c|c|c|c|c|c|c|c|}
\hline \multirow[t]{2}{*}{ S.No. } & \multirow{2}{*}{$\begin{array}{c}\text { Demography } \\
\text { Factor }\end{array}$} & & & & & & \\
\hline & & & $\begin{array}{c}\text { Nationalised } \\
\text { Bank }\end{array}$ & $\begin{array}{c}\text { Private } \\
\text { Bank }\end{array}$ & $\begin{array}{c}\text { Foreign } \\
\text { Bank }\end{array}$ & Total & $\begin{array}{l}\text { Gran } \\
d \\
\text { Total }\end{array}$ \\
\hline \multirow{4}{*}{1.} & \multirow{4}{*}{ Age in Years } & Less than 26 & 41 & 36 & 8 & 85 & \\
\hline & & 26 to 35 & 102 & 50 & 53 & 205 & \\
\hline & & 36 to 45 & 8 & 0 & 17 & 25 & \\
\hline & & Above 45 & 18 & 0 & 5 & 23 & 338 \\
\hline \multirow{5}{*}{2.} & \multirow{5}{*}{$\begin{array}{l}\text { Educational } \\
\text { Qualification }\end{array}$} & Plus 2 & 0 & 0 & 0 & 0 & \\
\hline & & Bachelor Degree & 93 & 0 & 30 & 123 & \\
\hline & & Master Degree & 35 & 52 & 8 & 95 & \\
\hline & & Professional & 41 & 34 & 38 & 113 & \\
\hline & & Doctoral & 0 & 0 & 7 & 7 & 338 \\
\hline \multirow{4}{*}{3.} & \multirow{4}{*}{$\begin{array}{c}\text { Experience in } \\
\text { Bank Job }\end{array}$} & Less than years & 52 & 23 & 14 & 89 & \\
\hline & & 3 to 4 years & 91 & 10 & 38 & 139 & \\
\hline & & 5 to 6 years & 0 & 23 & 26 & 49 & \\
\hline & & Above 6 years & 26 & 30 & 5 & 61 & 338 \\
\hline
\end{tabular}

Sources: Computed Data

From the above table, it is evident that 205employees are between 26 to 35 years. On examining the data, it is obvious that all the respondents hold UG as their degree. Out of the 338 respondents, 139 have more than 3 years. Employees of all cadres are covered.
Table 2- Descriptive Statistics

\begin{tabular}{|c|c|c|c|}
\hline Variables & Type of Bank & Mean & $\begin{array}{l}\text { Standerd } \\
\text { deviation }\end{array}$ \\
\hline \multirow[t]{3}{*}{ Group Cohesiveness } & Nationalizad bank & 3.6391 & .97279 \\
\hline & Private bank & 4.0116 & .78955 \\
\hline & Foreign bank & 3.9277 & 1.22756 \\
\hline \multirow{3}{*}{$\begin{array}{l}\text { Increases effective } \\
\text { communication with pers }\end{array}$} & Nationalizad bank & 4.2604 & .53755 \\
\hline & Private bank & 4.2674 & .65842 \\
\hline & Foreign bank & 2.2410 & .65501 \\
\hline \multirow[t]{3}{*}{ Reduces work stress- } & Nationalizad bank & 4.5621 & .58553 \\
\hline & Private bank & 4.0349 & .51900 \\
\hline & Foreign bank & 3.2289 & .94127 \\
\hline \multirow{3}{*}{$\begin{array}{l}\text { Reduces chaos and } \\
\text { confusion }\end{array}$} & Nationalised bank & 3.8580 & 1.11428 \\
\hline & Private bank & 4.2326 & .42494 \\
\hline & Foreign bank & 2.9277 & 1.03338 \\
\hline \multirow[t]{3}{*}{$\begin{array}{c}\text { Increases efficiency in } \\
\text { routine work }\end{array}$} & Nationalised bank & 4.1775 & .4 \\
\hline & Private bank & 4.5349 & .69786 \\
\hline & Foreign bank: & 3.6988 & .72809 \\
\hline \multirow[t]{3}{*}{ Increases interest in work } & Nationalised bank & 4.3550 & .570 \\
\hline & Private bank & 4.3837 & .48914 \\
\hline & Foreign bank & 3.8193 & 1.11688 \\
\hline \multirow{3}{*}{$\begin{array}{l}\text { Increases the level of } \\
\text { motivation }\end{array}$} & Nationalised bank & 4.1953 & .50330 \\
\hline & Private bank & 4.7674 & .42494 \\
\hline & Foreign bank & 3.8072 & 1.10936 \\
\hline \multirow{3}{*}{$\begin{array}{l}\text { Increases the level of job } \\
\text { satisfaction }\end{array}$} & Nationalised bank & 4.33 & .891 \\
\hline & Private bank & 4.15 & .604 \\
\hline & Foreign bank & 4.17 & \\
\hline \multirow[t]{3}{*}{ Helps in saving time } & Nationalised benk & 3.9408 & .9 \\
\hline & Private bank & 4.5349 & .50171 \\
\hline & Foreign bank & 4.0241 & 1.15796 \\
\hline \multirow[t]{3}{*}{ Enhances the skill } & Nationalised bank & 4.2544 & .534 \\
\hline & Private benk & 4.6512 & .47940 \\
\hline & Foreign bank: & 4.0482 & .79486 \\
\hline \multirow{3}{*}{$\begin{array}{l}\text { Increases confidence level } \\
\text { through training }\end{array}$} & Nationalised bank & 3.8284 & 1.25836 \\
\hline & Private bank: & 3.9535 & .94442 \\
\hline & Foreign bank & 4.1446 & .76720 \\
\hline \multirow{3}{*}{$\begin{array}{l}\text { Empowers to solve } \\
\text { problems }\end{array}$} & Nationalised bank & 3.6746 & .84 \\
\hline & \begin{tabular}{|l|} 
Private bank \\
\end{tabular} & 4.0000 & .48507 \\
\hline & Foreign bank & 3.1566 & .67140 \\
\hline \multirow{3}{*}{$\begin{array}{l}\text { Increases involvement in } \\
\text { decision making }\end{array}$} & Nationalised bank & 4.0651 & .89404 \\
\hline & Private bank & 4.2674 & .44522 \\
\hline & Foreign bank & 3.1807 & 1.00176 \\
\hline
\end{tabular}

Sources: Computed Data

The above table shows descriptive statistics for variables under investigation. Of all the mean values given the most important factor is "Increase in the level of motivation it has highest mean value of 4.7674and it is followed by "Enhances the skill" and its mean value is 4.6512 . From the above it is observed that the bank employees of all 3 types of bank have similar attitude.

\section{CHI-SQUARE TESTS}

$\mathbf{H}_{\mathbf{0}}$; There is no significant relationship between the bank group and the perception of bank Employees about the Ebanking.

$\mathbf{H}_{\mathbf{a}}$ : There is significant relationship between the bank group and the perception of bank Employees about the Ebanking. 
Table 3- chi-square tests

\begin{tabular}{|l|r|r|r|}
\hline Type ofE-Banking services & F & Sig. & $\begin{array}{l}\text { Result } \\
\text { (Rejected } \\
\text { /Accepted) }\end{array}$ \\
\hline 1.GroupCohesiveness & $65.625(\mathrm{a})$ & .000 & Rejected \\
\hline 2.Effective Communication with peers & $296.250(\mathrm{a})$ & .000 & Rejected \\
\hline 3.Reduces Work Stress & $185.788(\mathrm{a})$ & .000 & Rejected \\
\hline 4. reduces chaos and confusion & $155.133(\mathrm{a})$ & .000 & Rejected \\
\hline 5. increases efficiency in routine work & $130.637(\mathrm{a})$ & .000 & Rejected \\
\hline 6. increases interestin work & $49.307(\mathrm{a})$ & .000 & Rejected \\
\hline 7.increases Motivationin work & $118.451(\mathrm{a})$ & .000 & Rejected \\
\hline 8. increases thelevel of job satisfaction & $93.889(\mathrm{a})$ & .000 & Rejected \\
\hline 9. Helps in saving time & $94.010(\mathrm{a})$ & .000 & Rejected \\
\hline 10.enhances the skill & $61.519(\mathrm{a})$ & .000 & Rejected \\
\hline 11. increases the confidencelevel throughtraining & $63.187(\mathrm{a})$ & .000 & Rejected \\
\hline 12.Empowers to solveproblem- & $79.205(\mathrm{a})$ & .000 & Rejected \\
\hline 13.increases involvement in decision making & $114.370(\mathrm{a})$ & .000 & Rejected \\
\hline
\end{tabular}

From the above, it is inferred that the calculated probability value (p) is less than $5 \%(0.05)$. Hence, the $\mathrm{H}_{0}$ is rejected and reveals that there is a significant relationship between the perception of bank employees and the bank group in which they are employed.

\section{ANOVA TESTS}

$\mathbf{H}_{\mathbf{0}}$ : There is no significant difference between various bank group employees and the perception of E-banking services.

$\mathbf{H}_{\mathrm{a}}$ : There is significant difference between various bank group employees and the perception of E-banking services.

Table 2- one way anova

\begin{tabular}{|l|l|l|l|}
\hline Perception & F & Sig & $\begin{array}{l}\text { Accepted/ } \\
\text { Rejected }\end{array}$ \\
\hline Group Cohesiveness & 4.780 & .009 & Rejected \\
\hline Effective Communication with peers & 355.579 & .000 & Rejected \\
\hline Reduces workstress & 108.758 & .000 & Rejected \\
\hline Reduces chaos and confusion & 41.890 & .000 & Rejected \\
\hline Increases efficiency in routine work & 39.714 & .000 & Rejected \\
\hline Increases interestin work & 17.641 & .000 & Rejected \\
\hline Increases Motivation in work & 41.973 & .000 & Rejected \\
& & & \\
\hline Increases the level of job satisfaction & 2.136 & .120 & Accepted \\
\hline Helps in saving time & & & \\
\hline Enhances the skill & 12.512 & .000 & Rejected \\
\hline Increases the confidencelevel through training. & 2.401 & .000 & Rejected \\
\hline Empowers to solve problem & 28.886 & .000 & Rejected \\
\hline Increases involvement in decision making & 42.451 & .000 & Rejected \\
\hline
\end{tabular}

It is known that the probability value (p) of the perception that E-banking increases the level of job satisfaction is 0.120 is more than $5 \%(0.05)$. It implies that the $\mathrm{H}_{0}$ is accepted. While in all other variables the $\mathrm{H}_{0}$ is rejected. There is significant difference between various bank group employees and the perception of E-banking services.

\section{SUGGESTIONS}

- Banks are expected to be highly motivated to serve the typical customers.
- All the staffs are to be properly trained to work under Computerized environment.

- Proper vibes in the banks can develop a healthy work culture.

- The proper firewalls are to be installed to protect the system from hawkers.

- Employees have to be given proper health tips to protect them from the various health related hazards they face due to computerized working condition.

- The employees have to be given yoga and meditation facilities and practices to reduce their stress.

\section{CONCLUSION}

We are in the pinnacle of electronic world. All the services available in our palm top. With new innovations paving way for high expectation of customers, the bank employees are forced to equip themselves with the novel up gradation. This leads to a lot of stress especially among the middle aged employees. It is essential for banks to give training perpetually with changing milieu.

\section{RFERENCES}

1. E- banking: Problems and Prospects: An Empirical study in Punjab, Information management and Business Review, Vol.2, No.3, pp.118-124, (March 2011)

2. "Internet Banking problems and future on look" Kunal Books, New Delhi,2011, (pp.91-105). 